\title{
ANALISIS TEKNOLOGI INFORMASI MOBILE BANKING DAN PERSEPSI RISIKO TRANSAKSI TERHADAP KEPUASAN NASABAH (Studi Kasus Bank Mandiri Syariah Cabang Jemur Handayani Surabaya)
}

\author{
Djoko Soelistya, Heni Agustina \\ Universitas Nahdlatul Ulama Surabaya \\ e-mail: djoko_soelistya@unusa.ac.id \\ heni@unusa.ac.id
}

\begin{abstract}
In this era of technology now a very important role in the banking business the role of technology is absolute, where in the banking system of information technology is needed to support the progress of the banking system. The purpose of this research is to know about the effect of Information Technology of banking car and Risk Transaction Perception on Banking Customer Satisfaction, because many people only think about the interest in the use of banking facilities but not many banks know the feeling of satisfaction that exist within the customer over the facility. This research is quantitative research with explanative research type by doing observation because it explains the relation between variables through hypothesis testing without giving treatment with sample taken from a population using questionnaire as primary data gathering tool, and generally is unit of individual analysis. The population taken as many as 155 respondents, taken from the respondent employees UNUSA Yayasan RSI Surabaya. The results of this study found that a significant value variable Perception of Technology (X1) 0,000 <0.05; value of significance variable Perception on Transaction Risk (X2) 0,010<0,05; all the variables are very significant effect on Customer Satisfaction $(Y)$ and from the results of this study suggested that Bank Syariah Mandiri Jemur Handayani Surabaya can improve the quality of its services, therefore the quality of good service is an important variable factor to make customer satisfaction.
\end{abstract}

Keywords: car banking technology, risk perception, satisfaction

\section{PENDAHULUAN}

Pada era teknologi sekarang ini sudah begitu maju dan canggih, dengan menjadi peran yang sangat penting di dalam usaha bisnis khususnya bisnis perbankan. Pada lembaga keuangan khususnya dalam berbisnis di bidang perbankan sangat ketat dalam memperoleh nasabah, lembaga keuangan perbankan dituntut untuk meningkatkan pelayanan secara profesional sesuai dengan bidangnya masing-masing. Perubahan teknologi dan arus informasi yang sangat cepat telah mendorong lembaga keuangan untuk menghasilkan produk atau layanan yang dapat memenuhi kebutuhan dan keinginan nasabah, sehingga nasabah merasa puas dengan apa yang telah mereka dapatkan dari lembaga keuangan. Dengan pelayanan yang baik, maka nasabah akan merasa diperhatikan dan tidak diabaikan haknya.

Elektronik banking adalah fasilitas yang disediakan perusahaan perbankan melalui benda elektronik misalnya hand phone, computer, dan telepon untuk mengganti kebutuhan bertransaksi yang biasanya dilakukan oleh ATM. Dengan kata lain, nasabah dapat melakukan transaksi perbankan melalui hand phone ataupun internet seperti transaksi di mesin ATM. Elektronik banking membuka paradigma baru, struktur baru, dan strategi bagi retail bank, di mana bank menghadapi kesempatan dan tantangan 
yang baru, seperti yang disampaikan oleh Mukherjee (dalam Berliana Widiastuti, 2010).

Kasmir (2005) mengatakan kalau pentingnya pemasaran di bidang perbankan perlu adanya perhatian dan pemikiran dalam rangka memenuhi kebutuhan dan keinginan masyarakat akan suatu produk jasa. Pemasaran dan pemberian informasi perbankan akan menjadi semakin penting dengan semakin meningkatnya pengetahuan masyarakat dalam bidang teknologi informasi. Untuk itu, pemasaran juga dapat dilakukan dalam rangka menghadapi pesaing dari waktu ke waktu yang semakin meningkat. Para pesaing justru semakin gencar melakukan usaha pemasaran dalam rangka memasarkan produk jasanya.

Andika dan Indrawati (2015) mengatakan bahwa pelayanan nasabah yang berkualitas merupakan salah satu cara menghadapi persaingan serta hal utama yang akan berpengaruh terhadap kepuasan nasabah dan pernyataan ini juga dikuatkan oleh Gaby dan Peggy (2014) yang mengungkapkan bahwa kualitas layanan yang baik tidak hanya akan berpengaruh pada kepuasan saja melainkan juga berdampak pada loyalitas nasabah itu sendiri untuk tetap menggunakan jasa bank.

Pada sektor perbankan sangat membantu dalam bertransaksi dengan adanya perangkat komunikasi seperti perkembangan teknologi yang pada saat ini, perkembangan ini sangat berpengaruh pada para pengguna fasilitas perbankan seperti halnya nasabah bank melakukan transaksi dan layanan perbankan lainnya. Helza (2007:2) mengatakan bahwa perkembangan dan kemajuan di bidang teknologi informasi akan mempermudah nasabah bank untuk bertransaksi dimanapun nasabah memanfaatkan fasilitas yang ada tanpa perlu harus menunggu transaksi di kantor bank dengan bertransaksi mobil banking dan ini juga sejalan dengan Irmadhani dan Nugroho (2012) yang menyampaikan bahwa online banking adalah layanan transaksi perbankan yang dapat dilakukan oleh nasabah baik dari rumah, tempat usaha atau di lokasi-lokasi lain yang bukan di lokasi bank yang riil atau di kantor cabang dengan menggunakan media komunikasi seperti komputer, telepon seluler dan telepon rumah. Adapun layanan perbankan berbasis online yaitu seperti halnya automatic teller machine (ATM) dan mobil banking.

Teknologi informasi melalui transaksi mobil banking, mobil banking, dan ATM dapat digunakan untuk bermacam-macam pada transaksi perbankan secara online dan di antaranya adalah (a) untuk mengecek saldo rekening dan history transaksi bank; (b) membayar macam-macam tagihan; (c) transfer antar-account dan kegiatan transaksi perbankan ini diharapkan bank semakin berkembang sesuai kebutuhan setiap nasabah, karena mobil banking adalah customer based sehingga pangsa pasar yang dilayani diharapkan akan semakin luas.

Namun demikian, penggunaan fasilitas online perbankan selain mempermudah penggunaan dalam transaksi perbankan, nasabah perlu juga memperhatikan mengenai adanya pemanfaatan fasilitas-fasilitas tersebut, pemikiran dalam persepsi risiko bertransaksi yang dilakukan tanpa bertatap muka secara langsung serta persepsi dalam segi keamanannya. Risiko (risk) transaksi dan kelengkapan fitur layanan perbankan on line atau dikenal dengan mobile banking merupakan hal yang sangat dipertimbangkan dalam melakukan transaksi maya (virtual) karena jarak, kemampuan teknologi dalam memfasilitasi transaksi, layanan yang tidak bertatap muka dengan petugas perbankan atau disebut juga dengan teller/customer service sehingga pelayanan dan fasilitas yang dimiliki perbankan bisa memberikan dampak kepuasan para nasabahnya. 
Penggunaan fasilitas online perbankan selain mempermudah penggunaan dalam transaksi perbankan, nasabah perlu juga memperhatikan mengenai adanya pemanfaatan fasilitas-fasilitas tersebut, pemikiran dalam persepsi risiko bertransaksi yang dilakukan tanpa bertatap muka secara langsung serta persepsi dalam segi keamanannya. Risiko (risk) transaksi dan kelengkapan fitur layanan perbankan online atau dikenal dengan mobile banking merupakan hal yang sangat dipertimbangkan dalam melakukan transaksi maya (virtual) karena jarak, layanan yang tidak bertatap muka dengan petugas perbankan yang akan berdampak pada penggunanya/nasabah, artinya adanya teknologi dalam memfasilitasi transaksi, belum sampai memikirkan dampaknya antara lain adanya kepuasan nasabahnya, atas kemudahan-kemudahan yang diberikan karena inovasi produk harus diuji oleh penggunanya.

Berdasarkan latar belakang dan fenomena di atas maka perlu adanya perumusan untuk mengetahui analisis dari teknologi informasi mobil banking dan persepsi risiko transaksi memengaruhi kepuasan nasabah di Bank Syariah Mandiri Kantor Cabang Pembantu Jemur Handayani Surabaya.

\section{Teknologi Informasi}

Pada dunia bisnis pengembangan teknologi khususnya di bidang teknologi informasi, bahwa kata dari teknologi mengandung arti pengembangan dan penerapan berbagai peralatan atau sistem untuk menyelesaikan persoalan-persoalan yang dihadapi oleh manusia dalam kehidupan sehari-hari atau juga bisa disebut dengan pengembangan tata cara informatika. Azmi (2009: 2) mengatakan bahwa informasi adalah data yang diproses ke dalam bentuk yang lebih berarti bagi penerima dan berguna dalam pengambilan keputusan, baik dalam waktu sekarang atau untuk masa yang akan datang. Hal itu juga dikuatkan oleh pendapat Williams dan saywer dalam Seesar (2010:6) yang mengatakan teknologi informasi merupakan sebuah bentuk umum yang menggambarkan setiap teknologi yang membantu menghasilkan, memanipulasi, menyimpan, mengomunikasikan, dan atau menyampaikan informasi.

Dalam pengembangan teknologi informasi tidak lepas dengan yang dinamakan transaksi mobil banking, karena fitur layanan ini diharapkan bisa membantu kegiatan transaksi nasabah perbankan. Aplikasi teknologi informasi akan meningkatkan efisiensi, efektivitas, dan produktivitas sekaligus meningkatkan pendapatan melalui sistem penjualan yang jauh lebih efektif daripada bank konvensional. Tanpa adanya aplikasi teknologi informasi dalam mobil banking, maka mobil banking tidak akan berjalan dan dimanfaatkan oleh industri perbankan.

\section{Lingkup Teknologi Informasi}

Di dalam perangkat pendukung teknologi informasi dapat dibagi dalam dua bagian yaitu perangkat lunak (software) dan perangkat keras (hardware). Perangkat keras (hardware) seperti halnya peralatan-peralatan yang bersifat fisik seperti memori, printer, dan keyboard, sedangkan software atau perangkat lunak meliputi instruksiinstruksi untuk mengatur perangkat keras agar bekerja sesuai dengan tujuan instruksi tersebut (Kadir, 2003). Menurut Jamal M.A. (2011:164166) perangkat-perangkat teknologi informasi yang digunakan adalah sebagai berikut.

1) Komputer

Komputer adalah perangkat berupa hardware dan software yang digunakan untuk 
membantu manusia dalam mengolah data menjadi informasi dan menyimpannya untuk ditampilkan di lain waktu. Informasi yang dihasilkan komputer dapat berupa tulisan, gambar, suara, video, dan animasi.

2) Laptop/Notebook

Laptop/notebook adalah perangkat canggih yang fungsinya sama dengan komputer, tetapi bentuknya praktis dapat dilipat dan dibawa ke mana-mana.

3) Desk book

Deskbook adalah perangkat sejenis komputer dengan bentuknya yang jauh lebih praktis, yaitu CPU menyatu dengan monitor sehingga mudah diletakkan di atas meja tanpa memakan banyak tempat.

4) Personal digital assistant (PDA)/komputer genggam

PDA adalah perangkat sejenis komputer, tetapi bentuknya sangat mini sehingga dapat dimasukkan dalam saku. Walaupun begitu, fungsinya hampir sama dengan komputer pribadi yang dapat mengolah data.

5) Flash disk, CD, DVD, disket, memory card Flash disk adalah media penyimpanan data yang dapat menyimpan data dalam jumlah besar.

\section{Peranan Teknologi Informasi}

Kadir (2003) yang mengatakan bahwa peranan teknologi informasi meliputi hal-hal sebagai berikut.

a. Teknologi informasi menggantikan peran manusia. Dalam tugas ini, teknologi informasi melakukan otomasi terhadap suatu tugas atau proses.

b. Teknologi informasi memperkuat peran manusia, yakni dengan menyajikan informasi terhadap suatu tugas atau proses. c. Teknologi informasi berperan dalam restrukturisasi terhadap peran manusia.

\section{Persepsi Risiko}

Menurut Pavlou (2003), risiko transaksi adalah suatu keadaan uncertainty yang dipertimbangkan orang untuk memutuskan atau tidak melakukan transaksi secara online. Orang benarbenar mempertimbangkan jarak dan suasana impersonal dalam transaksi online dan infrastruktur global yang banyak mengandung unsur risiko. Risiko didefinisikan sebagai perkiraan subjektif konsumen untuk menderita kerugian dalam menerima hasil diinginkan. Dan Pavlou (2003) menyampaikan juga bahwa perceived of risk diukur dengan indikator sebagai berikut: (1) ada risiko tertentu, (2) mengalami kerugian, dan (3) pemikiran bahwa berisiko. Ada juga pemikiran bahwa berisiko yaitu suatu risiko yang belum terjadi saat akan melakukan transaksi jual beli melalui online shopping, sedangkan mengalami kerugian adalah suatu kejadian ketika sudah menggunakan online shopping pengguna mengalami kerugian.

Menurut Dowling dan Staelin dalam Pavlou (2001), kalau risiko itu meningkat dari sekadar informasi sampai pada keputusan pembelian produk (transaksi), risiko diasosiasikan dengan kepercayaan (kepercayaan). Dalam penelitian ini indikator risiko dilihat dari tindakan yang dilakukan oleh bank untuk memperkecil risiko dari penggunaan internet banking, diharapkan tindakan yang dilakukan oleh bank untuk memperkecil risiko akan berdampak positif pada minat konsumen untuk menggunakan teknologi yang ditawarkan.

Risiko (risk) transaksi merupakan hal yang sangat dipertimbangkan dalam melakukan transaksi maya (virtual) karena jarak, kemampuan 
teknologi dalam memfasilitasi transaksi, layanan yang tidak bertatap muka dengan teller/customer service dan banyak hal yang dipertimbangkan nasabah bank dalam transaksi melalui internet banking. Konsumen semakin terdorong untuk mencari tambahan informasi ketika dihadapkan pada pembelian produk dengan risiko tinggi.

Risiko persepsian menjadi lebih tinggi ketika:

1. sedikit tersedia informasi mengenai produk

2. produk tersebut merupakan produk baru

3. produk tersebut memiliki produk yang kompleks

4. rendahnya kepercayaan diri konsumen untuk mengevaluasi merek

5. tingginya harga produk

6. produk tersebut penting bagi konsumen

\section{DIMENSI PERSEPSI RISIKO}

Menurut Mulyadi Nitisusastro (2012) dalam Pebri Rochmawati dimensi persepsi risiko adalah sebagai berikut.

1. Risiko keuangan, yaitu risiko yang berkaitan dengan kekhawatiran akan menghadapi kesulitan dalam hal dana.

2. Risiko fungsional, yaitu risiko tentang fungsi berkaitan dengan dampak negative yang akan timbul apabila konsumen mengetahui dan memahami banyak produk yang kan dibeli tersebut mengandung sejumlah keburukan apabila dibeli dan dikonsumsi.

3. Risiko fisik, yaitu risiko yang terkait dengan kekhawatiran konsumen bahwa suatu produk dapat menyebabkan suatu bahaya fisik tertentu.

4. Risiko psikologis, yaitu risiko yang terkait dengan terjadinya dampak negatif akan melekat pada dirinya apabila ia membeli dan mengonsumsi barang tersebut.
5. Risiko sosial, yaitu risiko yang terkait dengan dampak negatif yang datang dari lingkungannya apabila ia membeli dan mengonsumsi barang tersebut.

6. Risiko waktu, yaitu risiko bahwa sebuah keputusan akan menghabiskan banyak waktu.

\section{KEPUASAN NASABAH}

Salah satu tujuan utama perusahaan jasa dalam hal ini adalah menciptakan kepuasan nasabah. Kepuasan nasabah sebagai hasil penilaian nasabah terhadap apa yang diharapkannya dengan membeli dan mengonsumsi suatu produk/ jasa. Kemudian harapan tersebut dibandingkan dengan kinerja yang diterimanya dengan mengonsumsi produk/jasa tersebut.

Menurut Kotler (2002:42) kepuasan adalah perasaan senang atau kecewa seseorang yang muncul setelah membandingkan antara persepsi atau kesannya terhadap kinerja atau hasil suatu produk dan harapan harapannya dan dikuatkan juga dengan pendapatnya Supranto (2001:224) bahwa kepuasan pelanggan merupakan perbedaan antara harapan dan kinerja yang dirasakan. Jadi, pengertian kepuasan pelanggan yaitu kinerja suatu barang sekurang-kurangnya sama dengan apa yang diharapkan.

Pengukuran kepuasan menurut Zeithaml, et al. (2006:130) yaitu variabel yang menggunakan indikator kepuasan pengguna teknologi layanan yang dilakukan sendiri seperti halnya berikut ini.

a) Mengatasi masalah saat dalam situasi yang sulit: konsumen akan merasa puas jika teknologi dapat mengatasi masalah/keperluan yang mendesak.

b) Lebih baik dari alternatif lain: konsumen akan merasa puas jika teknologi yang dilakukan lebih baik dari alternatif lain dari segi 
mudah digunakan, menghindari layanan personel, menghemat waktu, kapan pun, di mana pun, dan menghemat uang.

c) Melakukan tugasnya: karena banyak kegagalan teknologi maka konsumen akan merasa puas jika teknologi yang digunakan dapat berjalan sesuai fungsinya.

Menurut Kotler dalam Tjiptono (2005:336) ada empat metode yang banyak digunakan dalam mengukur kepuasan pelanggan.

1) Sistem keluhan dan saran.

2) Memberikan kesempatan seluas-luasnya bagi para pelanggan untuk menyampaikan saran, kritik, pendapat, dan keluhan mereka. Media yang digunakan bisa berupa kotak saran, komentar, saluran telepon khusus bebas pulsa, dan lain-lain.

3) Ghost shopping.

4) Salah satu metode untuk mengetahui gambaran mengenai kepuasan pelanggan adalah dengan mempekerjakan beberapa ghost shoppers untuk berperan sebagai pelanggan potensial jasa perusahaan dan pesaing.

5) Last customer analysis.

6) Perusahaan semestinya menghubungi para pelanggan yang telah berhenti membeli atau yang telah beralih pemasok agar dapat memahami mengapa hal ini terjadi dan supaya dapat mengambil kebijakan perbaikan dan penyempurnaan selanjutnya.

7) Survei kepuasan pelanggan.

8) Umumnya sebagian besar penelitian mengenai kepuasan pelanggan menggunakan metode survei baik via pos, telepon, email maupun wawancara langsung.

Kepuasan dan ketidakpuasan adalah respons nasabah terhadap evaluasi kesesuaian (disconfirmation) yang dirasakan antara harapan sebelumnya (norma kinerja lainnya) dengan kinerja aktual produk yang dirasakan setelah pemakaiannya.

\section{KERANGKA KONSEPTUAL}

Kepuasan nasabah sangat dipengaruhi oleh faktor internal dari nasabah itu sendiri yang meliputi faktor kelas sosial, kebudayaan, pribadi, dan psikologi. Selain itu, kepuasan nasabah juga dipengaruhi oleh faktor eksternal seperti halnya rangsangan pemasaran seperti unsur-unsur dalam marketing mix dan rangsangan lainnya seperti perekonomian, teknologi informasi, politik, dan budaya.

Kerangka pemikiran dalam penelitian ini dalam dua bagian, yaitu variable bebas (independent variables) $\mathrm{X}$, dan variabel terikat (dependent variable) $\mathrm{Y}$, yaitu klarifikasi variabel teknologi mobil banking(X1), persepsi risiko transaksi(X2), dan Kepuasan nasabah(Y).

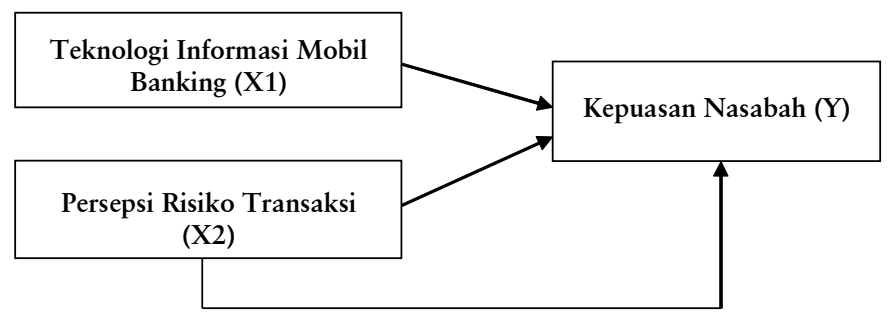

\section{HIPOTESIS PENELITIAN}

Berdasarkan latar belakang masalah, rumusan masalah, tinjauan pustaka, dan kerangka konseptual maka hipotesis penelitian disusun sebagai berikut.

H1: analisis teknologi informasi mobil banking dan persepsi risiko transaksi terhadap kepuasan nasabah.

H2: analisis teknologi informasi mobil banking dan persepsi risiko transaksi terhadap kepuasan nasabah.

\section{METODE PENELITIAN}

Rancangan penelitian ini merupakan penelitian kuantitatif dengan tipe penelitian penjelasan 
(explanative research) dengan melakukan pengamatan/non-eksperimen karena menjelaskan hubungan kalusal antara variabel-variabel melalui pengujian hipotesis tanpa memberikan perlakuan (Singarimbun, 2006:5), serta dengan sampel yang diambil dari suatu populasi dengan menggunakan kuesioner sebagai alat pengumpul data primer dan pada umumnya merupakan unit analisis individu.

\section{POPULASI}

Populasi adalah wilayah generalisasi yang terdiri atas banyak objek atau subjek yang mempunyai kualitas dan karakteristik tertentu yang ditetapkan oleh peneliti untuk dipelajari dan kemudian ditarik kesimpulannya (Sugiyono, 2009:119). Populasi dalam penelitian ini adalah pegawai UNUSA Yayasan RSI Surabaya.

\section{SAMPEL}

Teknik pengambilan sampel di sini adalah sampling jenuh yaitu teknik penentuan sampel bila semua anggota populasi digunakan sebagai sampel (Sugiyono, 2009:68).

Sampel adalah sebagian dari jumlah dan karakteristik yang dimiliki oleh populasi tersebut ataupun bagian kecil dari anggota populasi yang diambil menurut prosedur tertentu sehingga dapat mewakili populasinya. Jika populasi besar dan peneliti tidak mungkin mempelajari seluruh yang ada di populasi, hal seperti ini dikarenakan adanya keterbatasan dana atau biaya, tenaga, dan waktu maka peneliti dapat memakai sampel yang diambil dari populasi.

Untuk menentukan jumlah sampel yang mewakili populasi dalam penelitian digunakan rumus Slovin (Umar, 2004: 108) sebagai berikut:

$$
\mathrm{n}=\mathrm{N} /\left(1+\mathrm{N} \mathrm{e}^{\wedge} 2\right)
$$

Keterangan

$\mathrm{n}=$ ukuran sampel

$\mathrm{N}=$ ukuran populasi

$\mathrm{e}=$ nilai kritis

Dalam penelitian ini jumlah populasi karyawan dengan batas kesalahan yang diinginkan adalah $5 \%$.

\section{METODE ANALISIS DATA}

Analisis data merupakan suatu proses penyederhanaan data ke dalam bentuk yang lebih mudah dibaca dan diinterpretasikan. Dengan menggunakan metode kuantitatif, diharapkan akan didapatkan hasil pengukuran yang lebih akurat tentang respons yang diberikan oleh responden sehingga data yang berbentuk angka tersebut dapat diolah dengan menggunakan metode statistik.

\section{HASIL PENELITIAN DAN PEMBAHASAN}

\section{UJI VALIDITAS}

Validitas merupakan derajat ketepatan antara data yang terdapat di lapangan dan data yang di laporkan kepada peneliti. Menurut Sugiyono (2001:91) menyatakan bahwa "suatu instrumen dikatakan valid, jika pertanyaan pada kuesioner mampu mengungkapkan sesuatu yang akan diukur oleh kuesioner tersebut". Hasil Pengujian validitas yang dilakukan menggunakan program SPSS for windows versi 20. Dengan $r$ tabel $=0,157$, dan hasil uji validasi menyatakan bahwa variable X1 dan X2 di atas 0,157 (Valid)

\section{UJI RELIABILITAS}

Pengujian reliabilitas digunakan untuk memperoleh pengukuran yang konsisten jika dilakukan 
pengulangan pengukuran. Menurut Ghazali (2007:167) kriteria reliabilitas dikatakan reliabel jika koefisien Cronbach lebih besar dari 0,60 dan hasil uji reliabilitas menyatakan bahwa variabel X1 dan X2 di atas reliabel.

\section{Normal P-P Plot of Regression Standardized Residual}

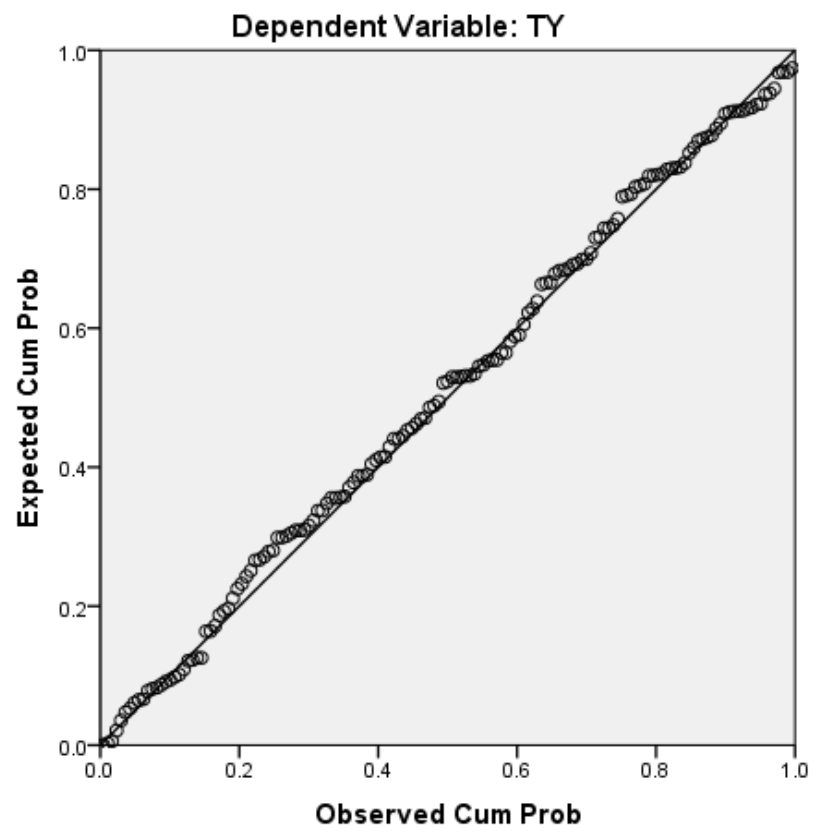

\section{UJI NORMALITAS}

Uji normalitas dilakukan untuk mengetahui apakah data yang diambil dalam penelitian berasal dari populasi yang berdistribusi normal atau tidak. Model regresi yang baik adalah yang datanya berdistribusi normal atau mendekati normal. Pengujian normalitas dalam penelitian ini yaitu melalui normal probability plot. Uji normalitas dengan normal probability plot mensyaratkan bahwa penyebaran data harus berada di sekitar wilayah garis diagonal dan mengikuti arah garis diagonal. Berdasarkan gambar di atas dapat disimpulkan bahwa data dalam penelitian ini memenuhi syarat normal probability plot sehingga model regresi dalam penelitian memenuhi asumsi normalitas (berdistribusi normal).

\section{UJI MULTIKOLINIERITAS}

Uji multikolinieritas bertujuan untuk menguji ada tidaknya korelasi antara variabel independent (bebas) dan variabel dependent (terikat) dalam suatu model regresi. Uji multikolinieritas dalam penelitian ini dilakukan dengan melihat nilai variance inflation factor (VIF).

Pada uji multikolinieritas, jika nilai VIF kurang dari 10 maka tidak terdapat korelasi dan hasil uji multikolinieritas bahwa nilai VIF yaitu analisis atas teknologi informasi mobil banking (X1) sebesar 1,161; dan persepsi atas risiko transaksi (X2) sebesar 1.089 kurang dari 10. Hal ini dapat disimpulkan bahwa tidak terdapat multikolinieritas antara variabel tidak saling mengganggu atau memengaruhi.

\section{UJI HETEROSKODESITAS}

Uji heteroskodesitas dilakukan dengan menggunakan uji korelasi Rank Spearman yaitu mengorelasikan antara absolut residual hasil regresi dengan semua variabel bebas. Bila signifikan hasil korelasinya lebih kecil dari 0.05 (5\%) maka persamaan regresi tersebut mengandung heteroskedastisitas dan sebaiknya berarti non heteroskedastisitas atau homoroskedastisitas. Hasil uji heteroskodesitas didapat variabel X1 sebesar 0,862; dan variabel X2 sebesar 0,919.

\section{UJI NORMALITAS}

Uji Normalitas dimaksudkan untuk mengetahui apakah residual yang diteliti berdistribusi normal atau tidak. Metode yang digunakan untuk menguji normalitas adalah dengan menggunakan uji Kolmogorov-Smirnov. Jika nilai signifikansi dari hasil uji Kolmogorov-Smirnov > 0,05 maka terdistribusi normal dan sebaliknya terdistribusi tidak normal. Hasil uji dengan menggunakan 
Kolmogorov-Smirnov menunjukkan bahwa nilai siginifikansi sebesar 0,916 $>0,05$, maka asumsi normalitas tersebut terpenuhi.

\section{PENGARUH SIMULTAN DENGAN UJI F}

Uji $\mathrm{F}$ dilakukan untuk menguji kesesuaian model regresi linier berganda. Uji F dalam penelitian ini dilakukan untuk menguji signifikansi pengaruh simultan antara variabel $\mathrm{X} 1$ dan variabel X2 terhadap variabel Y. Kriteria pengujian dengan uji $\mathrm{F}$ adalah dengan membandingkan nilai signifikansi dari nilai $\mathrm{F}(=0,05)$ dengan ketentuan $<0,05$ maka secara simultan berpengaruh signifikan atau bila $\mathrm{F}>0,05$ maka secara simultan tidak berpengaruh signifikan dan hasilnya dapat diketahui bahwa nilai signifikansi $0,000<0,05$, hal ini variabel X1 dan $\mathrm{X} 2$ secara simultan berpengaruh signifikan terhadap variabel Y.

\section{PENGARUH PARSIAL DENGAN UJI $t$}

Uji t dilakukan untuk menguji signifikansi pengaruh parsial antara variabel X1, X2, terhadap variabel Y. Kriteria pengujian dengan uji $\mathrm{t}$ adalah dengan membandingkan nilai signifikansi dari nilai $\mathrm{t}(=0,05)$ dengan ketentuan nilai signifikansi uji $\mathrm{t}<0,05$, maka variabel X1, X2 secara parsial berpengaruh signifikan terhadap variabel Y, bila uji t $>0,05$ maka secara parsial tidak berpengaruh signifikan. Hasil uji t X1 sebesar $0,000<0,005$, sedangkan X2 sebesar $0,010<0,05$ artinya variabel X1 dan X2 secara parsial berpengaruh signifikan.

\section{PENGUJIAN KOEFISIEN DETERMINASI (R2)}

Koefisien determinasi (R2) pada intinya mengukur seberapa jauh kemampuan model dalam menerangkan variasi variabel dependen. Nilai koefisien determinasi adalah antara nol dan satu. Nilai R2 yang kecil berarti kemampuan variabel-variabel independen dalam menjelaskan variasi variabel dependen sangat terbatas. Nilai yang mendekati satu berarti variabel-variabel independen memberikan hampir semua informasi yang dibutuhkan untuk memprediksi variasi variabel dependen (Ghozali, 2001: 83). Nilai koefisien determinasi ditentukan dengan nilai adjusted $\mathrm{R}$ square.

\begin{tabular}{|c|c|c|c|c|}
\hline Model & R & R Square & $\begin{array}{c}\text { Adjusted R } \\
\text { Square }\end{array}$ & $\begin{array}{c}\text { Std. Error of } \\
\text { the Estimate }\end{array}$ \\
\hline 1 &, $645^{\text {a }}$ &, 416 &, 400 &, 99773 \\
\hline
\end{tabular}

a. Predictors: (Constant), TX1, TX2

b. Dependent Variable: TY

Hasil perhitungan Uji R2 dapat diketahui bahwa koefisien determinasi (adjusted R2) yang diperoleh sebesar 0,416. Hal ini berarti 41,6\% variabel kepuasan nasabah dapat dijelaskan oleh variasi dari X1 dan X2, sedangkan 58,4\% dijelaskan oleh variabel lain.

\section{KESIMPULAN}

1. Uji Parsial antara variabel bebas persepsi atas teknologi (X1), terhadap keputusan pembelian $(\mathrm{Y})$, dengan nilai signifikansi $=0,000$. Nilai signifikansi variabel persepsi atas teknologi (X1)) $0,000<0,05$, hal ini menunjukkan variabel persepsi atas teknologi (X1) secara parsial berpengaruh signifikan terhadap kepuasan nasabah (Y).

2. Uji parsial antara variabel persepsi atas risiko transaksi (X3) terhadap kepuasan nasabah (Y) dengan nilai signifikansi $=0,010$. Nilai signifikansi variabel persepsi atas risiko transaksi (X2) $0,010<0,05$, hal ini menunjukkan variabel psikologis (X3) secara parsial ber- 
pengaruh signifikan terhadap kepuasan nasabah (Y).

3. Penelitian ini diketahui bahwa teknologi informasi mobil banking (X1) dan persepsi risiko transaksi (X2) berpengaruh simultan terhadap kepuasan nasabah (Y), dan dibuktikan dengan hasil uji $\mathrm{F}$ dapat diketahui bahwa nilai signifikansi $0,000<0,05$, hal ini menunjukkan bahwa persepsi atas teknologi informasi mobil banking (X1) dan secara simultan berpengaruh signifikan terhadap kepuasan nasabah $(\mathrm{Y})$.

\section{DAFTAR PUSTAKA}

Adamson, I. \& Shine, J. 2003. Extending the New Technology Acceptance Model to Measure the End User Information Systems Satisfaction in a Mandatory Environment: A Bank's Treasury. Technology Analysis \& Strategic Management, Vol. 15, No. 4, pp 441-455.

Ahmadi, Nugroho. 2012. "Faktor-Faktor yang Memengaruhi Intellectual Capital Disclosure”. Accounting Analysis Journal, 1 (2).

Andika dan Indrawati. 2016. Pengaruh Kualitas Layanan Mobile Banking Terhadap Kepuasan Nasabah Bank BCA di Kota Bandung Influence Of Mobile Banking Service Quality To Customer Satisfaction Bank BCA in Bandung. e-Proceeding of Management, Vol.3, No.3, Page 2879.

Azmi. 2012. "Islamic Banking and Economic Growth: the Indonesian Experience". International Journal of Islamic and Middle Eastern Finance and Management, Vol. 5, Issue: 1, pp.35-47.

David, D.S.a.O. 2005. The Relative Importance of Perceived Ease of Use in IS Adoption. O'Brian, David and Detmar Straub. The
Relative Importance a Study of e-Commerce Adoption Journal of the Association for Information System, pp. Vol. I, Article 8.

Gaby, et al. 2014. Kualitas Pelayanan dan Citra Merek Pengaruhnya Terhadap Kepercayaan Nasabah Bertransaksi e-Banking Melalui Kartu Debit Taplus BNI. Jurnal EMBA, Vol.2, No.2, Hal. 1261-1271.

Ghozali, I. 2012. Aplikasi Analisis Multivariate dengan Program IBM SPSS 20. Semarang: Badan Penerbit Universitas Diponegoro.

Gilang, A. 2010. Pengaruh Persepsi Teknologi Informasi, Kemudahan, Risiko, dan Fitur Layanan Terhadap Minat Ulang Nasabah Bank dalam Menggunakan Internet Banking (Studi pada Nasabah Bank BCA). Semarang: Penelitian Tidak Dipublikasikan Fakultas Ekonomi.

Ishak. 2008. Pengelolaan Perpustakaan Berbasis Teknologi Informasi. Jurnal Studi Perpustakaan dan Informasi, Vol. 4, No. 2, pp 87. Jamal M.A. 2011. 7 Tips Aplikasi PAKEM. Yogyakarta: DIVA Press.

Jogiyanto, H.M. 2008. Analisis dan Desain Sistem Informasi Pendekatan Terstruktur Teori dan Praktik Bisnis. Yogyakarta: Andi.

Jogiyanto, H.M. 2008. Sistem Teknologi informasi. Yogyakarta: Andi.

Kadir A. 2003. Pengenalan Sistem Informasi. Yogyakarta: Andi.

Khotler, Philip. 2000. Manajemen Pemasaran: Analisis, Perencanaan, Implementasi, dan Kontrol. Terjemahan: Hendra Teguh dan Ronny Antonius Rusly, Edisi 9, Jilid 1 dan 2. Jakarta: PT Prenhallindo.

Kotler, P.a.K.K. 2003. Manajemen Pemasaran. Jakarta: PT Indeks.

Lewis, W.V. 2003. Lewis, W."Sources of Influence on Beliefs about Information Techno- 
logy Use: An Empirical Study of Knowledge Workers,”. MIS Quarterly, pp. (27:4), pp. 657-678.

Mangin, Jean P.L., Bourgault N., dan Guerrero M.M. 2008. Modelling Perceived Usefulness on Adopting Online Banking through the TAM Model in A Canadian Banking Environment. Journal of Internet Banking and Commerce (Online), Vol. 16, No. 1 (http://www.arraydev.com/commerce/jibc/, diakses 23 September 2012).

Mas'ud, Fuad. 2004. Survei Diagnosis Organisasional (Konsep dan Aplikasi). Semarang: Badan Penerbit Universitas Diponegoro.

Mei S.C. 2014. Pengaruh Layanan Elektronik Banking (e-Banking) Terhadap Kepuasan Nasabah di BNI Syariah Kantor Cabang Pembantu Tulungagung. Penelitian Tidak Dipublikasikan. Tulungagung: Perbankan Syariah Fakultas Ekonomi dan Bisnis Islam Institut Agama Islam Negeri (Iain) Tulungagung.

Muhammad. 2004. Teknik Perhitungan bagi Hasil dan Profit Margin Pada Bank Syariah, hal. 42. Yogyakarta: UII Press.

Mukherjee, A. dan Nath, P. 2003. "A Model of Trust in Online Relationship Banking”. The International Journal of Bank Marketing Branford.

O'Brian, et al. 2005. "The Relative Importance of Perceived Ease of Use in IS Adoption: A Study of e-Commerce Adoption". Journal of the Association for Information System, Vol. I, Article 8.

Pavlou. 2002. Consumer Intention to Adopt Electronic Commerce Incorporating Trust and Risk in Technology Acceptance Model. Journal of Logistics Information Management.
Pavlou, F. 2001. Perceived Usefulness, Perceived Ease of Use and User Acceptance of Information Technology. s.l.: MIS Quarterly.

Pavlou, P.A. 2010. Consumer Acceptance of Electronic Commerce: Integrating Trust and Risk with the Technology Acceptance Model. International Journal of Electronic Commerce, p. Vol. 7 (3).

Pengaruh Kegunaan. 2016. Pengaruh Kegunaan, Persepsi Kemudahan, Persepsi Kenyamanan, Persepsi Risiko, dan Kepercayaan Terhadap Minat Menggunakan Internet Banking (Studi Kasus pada Bank BRI Unit Salatiga). Penelitian yang tidak Dipublikasikan. Salatiga: Fakultas Ekonomi dan Bisnis, Universitas Muhammadiyah.

Santoso S. 2000. Buku Latihan SPSS Statistik Parametrik. Jakarta: PT Elek Media Komputindo.

Santoso, S. 2000. Buku Latihan SPSS Statistik Parametrik. Jakarta: Elex Media Komputindo.

Sari, R. 2013. Pengaruh Persepsi Kebermanfaatan, Kepercayaan, dan Computer Self Efficacy Terhadap Penggunaan e-Banking pada Mahasiswa S1 Fakultas Ekonomi Universitas Negeri Yogyakarta. Penelitian yang Tidak Dipublikasikan. Yogyakarta: Fakultas Ekonomi Universitas Negeri Yogyakarta.

Seesar. 2010. Perbandingan Implementasi Insourcing, CoSourcing, dan Outsourcing Dalam Pengembangan Sistem Informasi. Majalah Ilmiah IPB.

Singarimbun, M.d.E. 1995. Metode Penelitian Survei. Jakarta: LP3ES.

Sugiyono. 2006. Statistik untuk Penelitian. Bandung: Alfabeta.

Sugiyono. 2010. Metode Penelitian Pendidikan (Pendekatan Kuantitatif, Kualitatif, dan R\&D). Bandung: CV Alfabeta. 
Supranto, J. 1998. Statistik Teori dan Aplikasi. Jakarta: Erlangga.

Sutarman. 2009. Pengantar Teknologi Informasi. Jakarta: Bumi Aksara.

Tjiptono, Fandy. 2005. Pemasaran Jasa, Edisi-1. Malang: Banyumedia.

Umar, H. 1998. Riset Sumber Daya Manusia dalam Organisasi. Jakarta: PT Gramedia Pustaka Utama.

Vebrika S.T. dan Helza. 2007. "Pengaruh Kualitas Jasa Internet Banking Terhadap Ke- puasan Konsumen. Thesis. Universitas Gunadarma.

Warjiyo. 2006. Stabilitas Sistem Perbankan dan Kebijakan Moneter: Keterkaitan dan Perkembangannya di Indonesia. Buletin Ekonomi Moneter dan Perbankan.

Zeithaml, et al. 2002. Service Quality Delivery through Websites: A Critical Review of Extant Knowledge. Academy of Marketing Science. 